\title{
Influence of Photoselective Films and Growing Season on Stem Growth and Flowering of Six Plant Species
}

\author{
Teresa A. Cerny, ${ }^{1}$ James E. Faust, Desmond R. Layne, and Nihal C. Rajapakse ${ }^{2}$ \\ Department of Horticulture, Clemson University, Clemson, SC 29634
}

\begin{abstract}
ADDITIONAL INDEX wORDs. light quality, photomorphogenesis, plant growth regulation, R:FR ratio, spectral filters
ABSTRACT. Growth chambers constructed of photoselective plastic films were used to investigate light quality effects on flowering and stem elongation of six flowering plant species under strongly inductive and weakly inductive photoperiods. Three films were used: a clear control film, a far red (FR) light absorbing $\left(A_{\mathrm{FR}}\right)$ film and a red $(R)$ light absorbing $\left(A_{R}\right)$ film. The $A_{\mathrm{FR}}$ and $A_{R}$ films intercepted FR (700 to $\left.800 \mathrm{~nm}\right)$ and $R(600$ to $700 \mathrm{~nm})$ wavelengths with maximum interception at 730 and $690 \mathrm{~nm}$, respectively. The phytochrome photoequilibrium estimates of transmitted light for the control, $\mathrm{A}_{\mathrm{FR}}$, and $A_{R}$ films were $0.71,0.77$, and 0.67 . The broad band R:FR ratios were $1.05,1.51$, and 0.77 , respectively. The photosynthetic photon flux was adjusted with neutral density filters to provide similar light transmission among chambers. Zinnia elegans Jacq., Dendranthema $\times$ grandiflorum Kitam. (chrysanthemum), Cosmos bipinnatus Cav., and Petunia $\times$ hybrida Vilm.-Andr. plants grown under the $A_{\mathrm{FR}}$ film were shorter than control plants. The $A_{\mathrm{FR}}$ film had no effect on height of Antirrhinum majus L. (snapdragon) or Rosa $\times$ hybrida (miniature rose). Anthesis of zinnia, chrysanthemum, cosmos (short-day plants), and miniature rose (day-neutral plant) was not influenced by the $A_{\mathrm{FR}}$ films. Anthesis of petunia and snapdragon (long-day plants) was delayed up to 13 days by $A_{\mathrm{FR}}$ films under weakly inductive photoperiods. In petunia, initiation and development of floral structures were not affected by the $A_{\mathrm{FR}}$ films during strongly inductive photoperiods. However, during weakly inductive photoperiods, initiation of the floral primordia was significantly delayed and overall development of the floral meristem was slower than control plants indicating that the $A_{\mathrm{FR}}$ films could increase the production time if long-day plants were produced off-season. Daylength extension with electric light sources could overcome this delay in anthesis yet achieve the benefit of $A_{\mathrm{FR}}$ films for height reduction without the use of chemical growth regulators.
\end{abstract}

The use of greenhouse covers that selectively absorb or reflect far red (FR) light presents an alternative means for chemical plant growth regulation. Plants grown in FR light deficient environments have shorter stems, similar to plants treated with chemical retardants (Mortensen and Stromme, 1987; Rajapakse and Kelly, 1992; vanHaeringen et al., 1998; Oyaert et al., 1999). The responses of a wide range of plants to modified light environments created by photoselective films with red (R) and FR light absorbing properties have been described. Most species studied are sensitive to light quality indicating that photoselective greenhouse covers can be an effective way to manipulate height in a wide range of plants (Cerny et al., 2000). Depending on the species, a $20 \%$ to $40 \%$ height reduction in chrysanthemum, tomato, bell pepper, and watermelon has been achieved with FR light absorbing photoselective films, compared to clear polyethylene films.

The transition from the vegetative to reproductive stage of photoperiod sensitive crops can be altered by light quality. Far red light deficient environments delayed flower initiation of chrysanthemum (Dendranthema $\times$ grandiflorum Kitam.) (Rajapakse and Kelly, 1995), coreopsis (Coreopsis x grandiflora Hogg ex Sweet), Campanula carpatica Jacq. (Runkle and Heins, 2001) and snapdragon (Antirrhinum majus L.) (Cremer et al., 1998) but $\mathrm{R}$ light deficient environments accelerated snapdragon flower development (vanHaeringen et al., 1998). With pansy (Viola xwittrockiana Gams.), a FR light deficient environment inhibited flower development (Runkle and Heins, 2001). Supplementing

Received for publication 10 June 2002. Accepted for publication 3 Apr. 2003. Technical contribution 4847 of the South Carolina Agricultural Experiment Station. The Fred C. Gloeckner Foundation and Mitsui Chemicals, Inc. Tokyo, Japan are gratefully acknowledged for the financial support. We thank James Reick of the Department of Experimental Statistics at Clemson University for helping with the data analysis and Sonja Maki of Department of Horticulture for her valuable suggestions and help with electron microscopy.

${ }^{1}$ Current address: Department of Plants, Soils, and Biometeorology, Utah State University, Logan, UT 84322-4820.

${ }^{2}$ Corresponding author: the growing environment with FR light reduced time to flower of Arabidopsis mutants (Bagnall, 1993). In snapdragon, increasing incandescent light, which has more FR than R light, promoted flowering (Cremer et al., 1998). Therefore, a concern with modifying a commercial greenhouse environment with photoselective films is any additional effects it may have on flower production schedules and flower quality.

For spectral filters to be used as a potential growth altering tool, a better understanding of their effects on time to flower on additional species must be established. The objective of this research was to investigate the influence of photoselective films containing $\mathrm{R}$ and FR light absorbing dyes on floral induction and subsequent development of selected long-day (LD), short-day (SD), and day-neutral (DN) plants.

\section{Materials and Methods}

Рhotoselective growth Chambers. Photoselective films containing $\mathrm{R}$ and FR light absorbing dyes that transmitted $75 \%$ photosynthetic photon flux $(P P F)$ were produced by Mitsui Chemicals, Inc., Japan and designated as FR light absorbing $\left(\mathrm{A}_{\mathrm{FR}}\right)$, and $\mathrm{R}$ light absorbing $\left(A_{R}\right)$ films. Growth chamber frames $(1.2 \times 1.2$ $\times 1.2 \mathrm{~m}$ ) made from PVC pipe were covered with these films and a clear (control) film that transmitted $90 \%$ PPF. The $P P F$ inside growth chambers was measured at three locations within each chamber between 1200 and $1400 \mathrm{HR}$ with a quantum meter (LI-185; LI-COR, Lincoln, Nebr.) fitted with a quantum sensor (LI-190SA). The $P P F$ was adjusted for uniformity in all chambers with neutral density filters. Two fans, one located at the top of the chamber and the other located on the opposite lower side, provided ventilation for the chambers. Two replicate chambers were used for each film treatment. The growth chambers were placed inside a clear double-layer polyethylene greenhouse. Greenhouse cooling/heating set points were $27 / 20^{\circ} \mathrm{C}$.

Spectral quality inside the chambers was measured on clear 


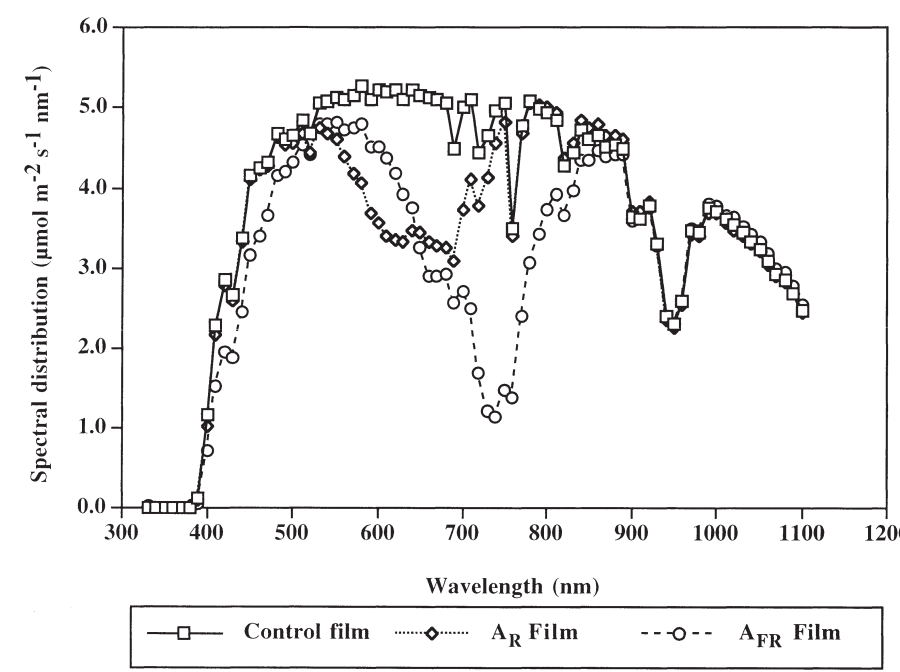

Fig. 1. Spectral transmission of sunlight through photoselective films. Clear, $A_{R}$, and $\mathrm{A}_{\mathrm{FR}}$ are control, red light, and far red light absorbing films, respectively.

days between 1200 and $1400 \mathrm{HR}$ at the beginning and end of each experiment using a spectroradiometer (LI-1800) fitted with a remote cosine sensor (LI-1800-10). Light transmission of sample photoselective films are shown in Fig. 1. The dyes in the $A_{F R}$ and $A_{R}$ films intercepted $F R$ and $R$ wavelengths with maximum absorptions at $730 \mathrm{~nm}$ and $690 \mathrm{~nm}$, respectively. The phytochrome photoequilibrium $\left(\mathrm{P}_{\mathrm{fr}} / \mathrm{P}_{\text {total }}\right)$ estimates of transmitted light for the control, $A_{F R}$, and $A_{R}$ films were $0.71,0.77$, and 0.67 , respectively (estimated as described by Sager et al., 1988). The broad band $R$ :FR ratios ( $R=600$ to $700 \mathrm{~nm}$; FR $=700$ to $800 \mathrm{~nm}$ ) for the control, $\mathrm{A}_{\mathrm{FR}}$, and $\mathrm{A}_{\mathrm{R}}$ films were $1.05,1.51$, and 0.77 , respectively. Daily minimum and maximum air temperatures were monitored using minimum/maximum thermometers. Daily light integrals (DLI) inside the photoselective chambers were recorded with a data logger (LI-1000) fitted with quantum sensors (LI-190SB) (programmed to collect readings every 5 min during each set of experiments.

EXPERIMENT 1. Flowering OF SELECTED SPECIES INSIDE PHOTOSELECTIVE CHAMBERS. Quantitative SD plants (chrysanthemum 'Iridon', zinnia 'Cherry Ruffles', and cosmos 'Sonata White'), quantitative LD plants (petunia 'Countdown Burgundy' and 'Supercascade Burgundy' and snapdragon 'Ribbon White'), and a DN plant (miniature rose 'Cherry Cupido') were used to evaluate the flowering response. Snapdragon, petunia, cosmos, and zinnia seeds were germinated under intermittent mist. At the first true leaf stage uniform seedlings were transplanted into $0.6 \mathrm{~L}$ plastic pots containing commercial potting medium (Fafard 3-B, Fafard Inc., Anderson, S.C.). Uniformly rooted cuttings of miniature rose and chrysanthemum (Yoder Brothers, Inc., Pendleton, S.C.) were planted directly into $0.6 \mathrm{~L}$ pots. All plants were moved into the treatment chambers after transplanting. Plants were watered as needed with water containing $1 \mathrm{~g} \cdot \mathrm{L}^{-1}$ of a $20 \mathrm{~N}-4.4 \mathrm{P}-16.7 \mathrm{~K}$ water soluble fertilizer (Peters 20-10-20 Peat-Lite Special, ScottsSierra Horticultural Products Co., Marysville, Ohio) during the experiment.

The experiment was conducted from November through January when the average daily photoperiod ranged from 10 to 11 $h \cdot d^{-1}$. The photoperiod was determined based on the U.S. Naval Observatory Sunrise and Sunset table for Greenville, S.C. Plants received a DLI of 9 to $10 \mathrm{~mol} \cdot \mathrm{m}^{-2} \cdot \mathrm{d}^{-1}$ during the experimental period. Hourly day and night temperatures were not recorded in the experiments reported here due to technical difficulties. The average daily maximum and minimum temperatures were not significantly different among chambers, averaging $33 \pm 2{ }^{\circ} \mathrm{C}$ and $15 \pm 2{ }^{\circ} \mathrm{C}$, respectively.

EXPERIMENT 2. INTERACTION BETWEEN PHOTOSELECTIVE FILMS AND GROWING SEASON ON FLOWERING OF SELECTED SPECIES. BaSed on the results of the previous experiment, zinnia 'Cherry Ruffles' (SD plant) and petunia 'Supercascade Burgundy'(LD plant) were selected for further investigation for potential seasonal interactions on flower development under photoselective films. Zinnia and petunia plants were grown inside the photoselective and control chambers as previously described during strongly inductive and weakly inductive photoperiods for each species. Eight plants of each species were grown to flowering in each chamber. Days from start of treatment to anthesis, average flower diameter, number of flowers and buds per plant, plant height, and shoot dry weight were recorded.

To investigate the anatomical changes taking place in the apical meristem, 40 plants of each species were grown in each chamber. Apices from three plants of each species in each chamber were harvested every $3 \mathrm{~d}$ until the visible bud stage. These meristems were exposed, fixed in $3 \%$ glutaraldehyde and dehydrated with an ethanol series $(50 \%, 70 \%, 80 \%, 95 \%$, and $100 \%)$. They were then critical point dried through $\mathrm{CO}_{2}$, mounted on stubs and coated with gold using a sputterer coater. Lastly, the apices were examined and photographed using a scanning electron microscope (Hitachi S-3500N, Hitachi Instruments Ltd., Japan).

Changes in the meristem were evaluated based on the following criteria for zinnia (Kim et al., 1989): stage (1) vegetative, leaf primordia formed oppositely; (2) bract formation; (3) early floret formation, petal primordia developed and the sepal primordia appeared at the base of petal primordia; (4) late floret formation, the stamen primordia were larger and more developed; and (5) further development of floral structures. The stages of the petunia meristem were based on the following criteria: stage (1) vegetative, formation of leaf primordia; (2) bract and petal formation; (3) development of anthers on floral meristem; (4) development of stigma on floral meristem; and (5) further development of floral structures. At each sampling, meristem development was rated based on the above criteria.

Experiments with each species were conducted under strongly inductive and weakly inductive photoperiods. Zinnia experiments were conducted during January-March and June-July when photoperiods averaged 10.5 to $11.5 \mathrm{~h} \cdot \mathrm{d}^{-1}$ (strongly inductive) and 14 to $14.5 \mathrm{~h} \cdot \mathrm{d}^{-1}$ (weakly inductive). Petunia experiments were conducted during May-June and February-April when photoperiods averaged 13 to $14.5 \mathrm{~h} \cdot \mathrm{d}^{-1}$ (strongly inductive) and 11 to $13 \mathrm{~h} \cdot \mathrm{d}^{-1}$ (weakly inductive), respectively. Average maximum/minimum air temperatures inside the chambers for the zinnia experiments during strongly inductive and weakly inductive photoperiods were $34 \pm 1 / 16 \pm 1{ }^{\circ} \mathrm{C}$ and $40 \pm 3 / 21 \pm 1{ }^{\circ} \mathrm{C}$, respectively. Plants were only exposed to the higher temperatures for a short period during the day. Zinnia plants received $\approx 9.0$ and $16.5 \mathrm{~mol} \cdot \mathrm{m}^{-2} \cdot \mathrm{d}^{-1}$ of $P P F$ during strongly inductive and weakly inductive photoperiods, respectively. Average minimum/maximum air temperatures inside the chambers for petunia experiments during strongly inductive and weakly inductive photoperiods were $39 \pm 2 / 19 \pm 1{ }^{\circ} \mathrm{C}$ and $35 \pm 2 / 16 \pm 2{ }^{\circ} \mathrm{C}$, respectively. Petunia plants received 25.0 and $11.5 \mathrm{~mol} \cdot \mathrm{m}^{-2} \cdot \mathrm{d}^{-1}$ of $P P F$ during strongly inductive and weakly inductive photoperiods, respectively.

EXPERIMENTAL DESIGN AND DATA ANALYSIS. Six photoselective film chambers (two replicates per treatment) were randomly placed 
inside the greenhouse. The experimental design was a completely randomized design. In Expt.1, six plants from each species were randomly arranged within each photoselective chamber. In Expt 2 , eight plants were used for flowering evaluation and three plants per sampling period were used for anatomical evaluations in each chamber. Days to flower (anthesis), average flower diameter, number of flowers per plant, and plant height (height from the top of the soil to the apex) were recorded at flowering. At the end of the experiment, shoot dry weight was recorded after drying for $48 \mathrm{~h}$ at $70{ }^{\circ} \mathrm{C}$. Data were analyzed using analysis of variance procedures of SAS and means compared using LSD test at $P=$ 0.05 (SAS Inst., Inc., Cary, N.C.).

\section{Results and Discussion}

EXPERIMENT 1. FloWERING OF SELECTED SPECIES INSIDE PHOTOSELECTIVE CHAMBERS. Quantitative SD plants, zinnia, cosmos, and chrysanthemum, grown under the $\mathrm{A}_{\mathrm{FR}}$ film were significantly shorter and had a lower shoot dry weight compared to control plants (Table 1). The $A_{R}$ film had no effect on stem elongation of zinnia and cosmos but slightly increased stem elongation of chrysanthemum. Plants grown under $A_{R}$ film had a lower shoo dry weight compared to the control plants. Total number of nodes at flowering was not different among treatments (data not shown). Days to anthesis of zinnia and chrysanthemum plants was slightly

Table 1. Influence of red $\left(A_{R}\right)$ and far red $\left(A_{F R}\right)$ light absorbing greenhouse films on stem length, shoot dry weight, days to anthesis, and average flower diameter of selected crops. The experiment was conducted between November and January. Control is a clear polyethylene film.

\begin{tabular}{|c|c|c|c|c|}
\hline Film & $\begin{array}{l}\text { Stem } \\
\text { length } \\
(\mathrm{cm})\end{array}$ & $\begin{array}{c}\text { Shoot } \\
\text { dry } \\
\text { wt (g) }\end{array}$ & $\begin{array}{l}\text { Days to } \\
\text { anthesis }\end{array}$ & $\begin{array}{r}\text { Flowe } \\
\text { diam } \\
(\mathrm{cm})\end{array}$ \\
\hline & \multicolumn{4}{|c|}{ Zinnia elegans Cherry Ruffles ${ }^{z}$} \\
\hline Control & $38.0 \mathrm{a}^{\mathrm{x}}$ & $10.8 \mathrm{a}$ & $35 \mathrm{c}$ & $7.5 \mathrm{a}$ \\
\hline$A_{F R}$ & $30.4 \mathrm{~b}$ & $8.0 \mathrm{c}$ & $37 \mathrm{a}$ & $7.2 \mathrm{a}$ \\
\hline \multirow[t]{2}{*}{$A_{R}$} & $40.9 \mathrm{a}$ & $9.8 \mathrm{~b}$ & $36 \mathrm{~b}$ & $7.5 \mathrm{a}$ \\
\hline & \multicolumn{4}{|c|}{ Cosmos bipinnatus Sonata White ${ }^{z}$} \\
\hline Control & $40.8 \mathrm{a}$ & $2.8 \mathrm{a}$ & $26 \mathrm{a}$ & $7.5 \mathrm{a}$ \\
\hline $\mathrm{A}_{\mathrm{FR}}$ & $37.3 \mathrm{~b}$ & $2.0 \mathrm{~b}$ & $27 \mathrm{a}$ & $7.3 \mathrm{a}$ \\
\hline \multirow[t]{2}{*}{$A_{R}$} & $42.7 \mathrm{a}$ & $2.3 \mathrm{~b}$ & $27 \mathrm{a}$ & $7.0 \mathrm{a}$ \\
\hline & \multicolumn{4}{|c|}{ Dendranthema $\times$ grandiflorum Iridon $^{z}$} \\
\hline Control & $22.4 \mathrm{~b}$ & $11.0 \mathrm{a}$ & $53 \mathrm{~b}$ & $8.4 \mathrm{a}$ \\
\hline $\mathrm{A}_{\mathrm{FR}}$ & $20.1 \mathrm{c}$ & $8.6 \mathrm{c}$ & $55 \mathrm{a}$ & $8.2 \mathrm{a}$ \\
\hline \multirow[t]{2}{*}{$A_{R}$} & $23.6 \mathrm{a}$ & $10.1 \mathrm{~b}$ & $53 \mathrm{~b}$ & $8.5 \mathrm{a}$ \\
\hline & \multicolumn{4}{|c|}{ Antirrhinum majus Ribbon Whitey } \\
\hline Control & $48.3 \mathrm{~b}$ & $9.8 \mathrm{a}$ & $63 \mathrm{~b}$ & --- \\
\hline $\mathrm{A}_{\mathrm{FR}}$ & $48.9 \mathrm{~b}$ & $7.7 \mathrm{~b}$ & $70 \mathrm{a}$ & --- \\
\hline \multirow[t]{2}{*}{$A_{R}$} & $53.8 \mathrm{a}$ & $9.4 \mathrm{a}$ & $61 \mathrm{~b}$ & --- \\
\hline & \multicolumn{4}{|c|}{ Petunia $\times$ hybrida Supercascade Burgundyy } \\
\hline Control & --- & $15.3 \mathrm{a}$ & $53 \mathrm{~b}$ & $10.0 \mathrm{a}$ \\
\hline $\mathrm{A}_{\mathrm{FR}}$ & --- & $11.2 \mathrm{~b}$ & $66 \mathrm{a}$ & $9.6 \mathrm{~b}$ \\
\hline \multirow[t]{2}{*}{$A_{R}$} & --- & $14.4 \mathrm{a}$ & $54 \mathrm{~b}$ & $10.2 \mathrm{a}$ \\
\hline & \multicolumn{4}{|c|}{ Rosa $\times$ hybrida Cherry Cupido } \\
\hline Control & $28.8 \mathrm{a}$ & $11.9 \mathrm{a}$ & $46 \mathrm{a}$ & $3.3 \mathrm{a}$ \\
\hline $\mathrm{A}_{\mathrm{FR}}$ & $27.2 \mathrm{a}$ & $10.8 \mathrm{a}$ & $46 \mathrm{a}$ & $3.3 \mathrm{a}$ \\
\hline$A_{R}$ & $29.2 \mathrm{a}$ & $11.9 \mathrm{a}$ & $46 \mathrm{a}$ & $3.4 \mathrm{a}$ \\
\hline
\end{tabular}

Inductive photoperiods for the species.

yess inductive photoperiods for the species.

xEach mean is the average of 12 plants. Mean separation within a species was by LSD test, $P=0.05$. Means with the same letter within a species are not significantly different. delayed ( $2 \mathrm{~d}$ ) under the $\mathrm{A}_{\mathrm{FR}}$ films but had no effect on anthesis of cosmos. In general, the $A_{R}$ film had no effect on flowering of SD plants tested. Average flower diameter was similar among all treatments. Rajapakse and Kelly (1995) reported that FR light deficient environments delayed anthesis of 'Bright Golden Anne' chrysanthemum by 7 to $13 \mathrm{~d}$ (depending on the growing season) and produced smaller flowers. In 'Spears' chrysanthemum, however, McMahon et al. (1991) reported that FR light deficient environments did not affect time to anthesis under strongly inductive photoperiods but promoted flowering under weakly inductive photoperiods compared to control plants.

Anthesis of snapdragon and petunia under the $A_{\mathrm{FR}}$ film was delayed by 7 and $13 \mathrm{~d}$, respectively (Table 1). The $\mathrm{A}_{\mathrm{FR}}$ film did not affect stem elongation of snapdragon but reduced shoot dry weight of both snapdragon and petunia. Anthesis and shoot dry weight of plants grown under the $A_{R}$ film were similar to the control plants. These results are in agreement with vanHaeringen et al. (1998) who reported that snapdragon plants grown under an $\mathrm{A}_{\mathrm{FR}}$ film flowered $9 \mathrm{~d}$ later than the control plants. However, in contrast to our findings, they reported that snapdragon grown under an $A_{\mathrm{FR}}$ film were shorter than control plants. In growth room studies, increasing the proportion of incandescent light (decreased R:FR) induced earlier flowering and reduced leaf number of snapdragon (Cremer et al., 1998).

Photoselective films did not influence growth and flowering of miniature rose. Plant height, shoot dry weight, days to anthesis, and flower diameter under the $\mathrm{A}_{\mathrm{FR}}$ and $\mathrm{A}_{\mathrm{R}}$ films were similar to the control plants (Table 1). These results demonstrate the variability in response of species to modified light environments.

Table 2. Influence of red $\left(A_{R}\right)$ and far red $\left(A_{F R}\right)$ light absorbing films on stem length, shoot dry weight, and days to anthesis under inductive and less inductive photoperiods for zinnia and petunia.

\begin{tabular}{|c|c|c|c|c|}
\hline Filter & Photoperiod & $\begin{array}{c}\text { Stem } \\
\text { length } \\
(\mathrm{cm})\end{array}$ & $\begin{array}{l}\text { Shoot } \\
\text { dry wt } \\
\text { (g) }\end{array}$ & $\begin{array}{l}\text { Days to } \\
\text { anthesis }\end{array}$ \\
\hline & & \multicolumn{3}{|c|}{ Zinnia elegans Cherry Ruffles } \\
\hline Control & Strongly inductive & $38.0 \mathrm{a}^{\mathrm{z}}$ & $10.8 \mathrm{a}$ & $35 \mathrm{a}$ \\
\hline $\mathrm{A}_{\mathrm{FR}}$ & & $30.4 \mathrm{~b}$ & $8.0 \mathrm{c}$ & $37 \mathrm{a}$ \\
\hline $\mathrm{A}_{\mathrm{R}}$ & & $40.9 \mathrm{a}$ & $9.8 \mathrm{~b}$ & $36 a$ \\
\hline Control & Weakly inductive & $46.0 \mathrm{a}$ & $6.3 \mathrm{a}$ & $23 \mathrm{a}$ \\
\hline $\mathrm{A}_{\mathrm{FR}}$ & & $42.0 \mathrm{~b}$ & $6.0 \mathrm{a}$ & $23 \mathrm{a}$ \\
\hline$A_{R}$ & & $47.8 \mathrm{a}$ & $6.4 \mathrm{a}$ & $23 \mathrm{a}$ \\
\hline \multicolumn{5}{|l|}{ ANOVA } \\
\hline Film & $* * *$ & $* * *$ & NS & \\
\hline Photop & eriod $* * *$ & $* * *$ & $* * *$ & \\
\hline \multicolumn{2}{|c|}{ Film $\times$ photoperiod } & NS & $* * *$ & NS \\
\hline & & \multicolumn{3}{|c|}{ Petunia xhybrida Countdown Burgundy } \\
\hline Control & Strongly inductive & $13.4 \mathrm{a}$ & $6.5 \mathrm{a}$ & $26 \mathrm{a}$ \\
\hline $\mathrm{A}_{\mathrm{FR}}$ & & $12.1 \mathrm{~b}$ & $5.3 \mathrm{~b}$ & $27 \mathrm{a}$ \\
\hline $\mathrm{A}_{\mathrm{R}}$ & & $13.8 \mathrm{a}$ & $5.8 \mathrm{ab}$ & $26 \mathrm{a}$ \\
\hline Control & Weakly inductive & $14.8 \mathrm{a}$ & $7.2 \mathrm{a}$ & $28 \mathrm{~b}$ \\
\hline $\mathrm{A}_{\mathrm{FR}}$ & & $13.0 \mathrm{~b}$ & $5.3 \mathrm{~b}$ & $33 \mathrm{a}$ \\
\hline $\mathrm{A}_{\mathrm{R}}$ & & $16.2 \mathrm{a}$ & $6.0 \mathrm{ab}$ & $29 \mathrm{~b}$ \\
\hline \multicolumn{5}{|l|}{ ANOVA } \\
\hline Film & & * & ** & * \\
\hline Photop & eriod & * & NS & *** \\
\hline Film $\times$ & photoperiod & NS & NS & NS \\
\hline
\end{tabular}

${ }^{\mathrm{z}}$ Each mean is the average of 16 plants. Mean separation within a species and photoperiod was by LSD test, $P=0.05$. Means with the same letter within a species and photoperiod are not significantly different.

Ns, $, * * *, * * * *$ Nonsignificant or significant at $P=0.05,0.01$, or 0.001 , respectively. 
EXPERIMENT 2. INTERACTION BETWEEN PHOTOSELECTIVE FILMS AND GROWING SEASON ON STEM GROWTH AND FLOWERING OF ZINNIA AND PETUNIA. Zinnia 'Cherry Ruffles' is a quantitative SD species in which floral initiation and development are accelerated under photoperiods that are $12 \mathrm{~h} \cdot \mathrm{d}^{-1}$ or less (Boyle and Stimart, 1983). Time to anthesis of zinnia was not significantly affected by the photoselective films during strongly inductive or weakly inductive photoperiods. In general, zinnias grown under weakly inductive photoperiods were taller and had lower total shoot dry weights than plants grown under strongly inductive photoperiods (Table 2). The shoot dry weight per unit length of stem (shoot dry weight/stem length) in zinnia grown under weakly inductive photoperiods was $\approx 35 \%$ less than that of plants grown under strongly inductive photoperiods. Zinnias grown in $\mathrm{A}_{\mathrm{FR}}$ film chambers were $20 \%$ shorter than control plants under strongly inductive photoperiods, but only $9 \%$ shorter than control plants under weakly inductive photoperiods. Total shoot dry weight of zinnia was $26 \%$ lower under the $\mathrm{A}_{\mathrm{FR}}$ films during strongly inductive photoperiods but was not significantly different from plants grown during weakly inductive photoperiods. However, shoot dry weight per unit length of stem was only slightly reduced (7\%) by the $\mathrm{A}_{\mathrm{FR}}$ film indicating the reduction in total shoot dry weight was mainly due to the smaller plant size, not due to reduced dry

Table 3. Influence of red $\left(\mathrm{A}_{\mathrm{R}}\right)$ and far red $\left(\mathrm{A}_{\mathrm{FR}}\right)$ light absorbing films on floral initiation and developmental stages of petunia and zinnia during inductive and less inductive photoperiods. Each number is the average for of six apices harvested at each sampling period.

\begin{tabular}{|c|c|c|c|c|c|c|}
\hline Film & Photoperiod & \multicolumn{5}{|c|}{ Avg developmental stage ${ }^{z}$} \\
\hline & & \multicolumn{5}{|c|}{ Zinnia elegans Cherry Ruffles } \\
\hline & & \multicolumn{5}{|c|}{ Days after initiation of treatment } \\
\hline & & 12 & 15 & 18 & 21 & \\
\hline Control & Strongly inductive & $1.7 \mathrm{y} a^{x}$ & $2.7 \mathrm{a}$ & $4.0 \mathrm{a}$ & $5.0 \mathrm{a}$ & \\
\hline $\mathrm{A}_{\mathrm{FR}}$ & & $1.5 \mathrm{a}$ & $2.0 \mathrm{a}$ & $3.0 \mathrm{~b}$ & $4.3 \mathrm{~b}$ & \\
\hline \multirow{3}{*}{\multicolumn{2}{|c|}{$\mathrm{A}_{\mathrm{R}}$}} & $1.3 \mathrm{a}$ & $2.5 \mathrm{a}$ & $4.0 \mathrm{a}$ & $5.0 \mathrm{a}$ & \\
\hline & & \multicolumn{5}{|c|}{ Days after initiation of treatment } \\
\hline & & 5 & 8 & 11 & 14 & \\
\hline Control & Weakly inductive & $1.8 \mathrm{a}$ & $3.0 \mathrm{a}$ & $4.0 \mathrm{a}$ & $5.0 \mathrm{a}$ & \\
\hline $\mathrm{A}_{\mathrm{FR}}$ & & $2.2 \mathrm{a}$ & $3.0 \mathrm{a}$ & $4.0 \mathrm{a}$ & $5.0 \mathrm{a}$ & \\
\hline \multirow[t]{3}{*}{$\mathrm{A}_{\mathrm{R}}$} & & $2.0 \mathrm{a}$ & $3.8 \mathrm{a}$ & $4.5 \mathrm{a}$ & $5.0 \mathrm{a}$ & \\
\hline & & \multicolumn{5}{|c|}{$\begin{array}{c}\text { Petunia } \times \text { hybrida } \text { Countdown Burgundy } \\
\text { Days after initiation of treatment }\end{array}$} \\
\hline & & 7 & 10 & 13 & 16 & 19 \\
\hline Control & Strongly inductive & $1.0 \mathrm{a}$ & $1.3 \mathrm{a}$ & $2.5 \mathrm{a}$ & $3.3 \mathrm{a}$ & $5.0 \mathrm{a}$ \\
\hline $\mathrm{A}_{\mathrm{FR}}$ & & $1.0 \mathrm{a}$ & $1.8 \mathrm{a}$ & $2.5 \mathrm{a}$ & $3.0 \mathrm{a}$ & $5.0 \mathrm{a}$ \\
\hline \multirow[t]{3}{*}{$A_{R}$} & & $1.0 \mathrm{a}$ & $1.8 \mathrm{a}$ & $2.7 \mathrm{a}$ & $3.4 \mathrm{a}$ & $5.0 \mathrm{a}$ \\
\hline & & \multicolumn{5}{|c|}{ Days after initiation of treatment } \\
\hline & & 11 & 14 & 17 & 20 & \\
\hline Control & Weakly inductive & $2.7 \mathrm{a}$ & $3.0 \mathrm{a}$ & $4.0 \mathrm{a}$ & $5.0 \mathrm{a}$ & \\
\hline $\mathrm{A}_{\mathrm{FR}}$ & & $1.2 \mathrm{~b}$ & $3.0 \mathrm{a}$ & $3.6 \mathrm{a}$ & $4.0 \mathrm{~b}$ & \\
\hline $\mathrm{A}_{\mathrm{R}}$ & & $2.5 \mathrm{a}$ & $3.0 \mathrm{a}$ & $4.0 \mathrm{a}$ & $5.0 \mathrm{a}$ & \\
\hline
\end{tabular}

zDevelopmental stages for zinnia: 1 = vegetative, leaf primordia formed oppositely; 2 = bract formation; $3=$ early floret formation, petal primordia developed and the sepal primordia appeared at the base of petal primordial; 4 = late floret formation, the stamen primordia were larger and more developed; 5 = further development of floral structures. Developmental stages for petunia: $1=$ vegetative, formation of leaf primordial; $2=$ bract and petal formation; 3 = development of anthers on floral meristem; 4 $=$ development of stigma on floral meristem; 5 = further development of floral structures.

y Average developmental stage of meristem at the time of sampling. xMean separation by species and photoperiod within a row by LSD test, $P=0.05$. matter assimilation. The difference in growth during weakly inductive and strongly inductive photoperiods could be partly due to the variation in environmental conditions between two seasons. During the weakly inductive photoperiods, zinnia plants received more light (16.5 and $9 \mathrm{~mol} \cdot \mathrm{m}^{-2} \cdot \mathrm{d}^{-1}$ during weakly inductive and strongly inductive photoperiods, respectively) and were exposed to higher temperatures than the plants grown during strongly inductive photoperiods (maximum/minimum of $34 \pm 1 / 16 \pm 1{ }^{\circ} \mathrm{C}$ under strongly inductive and of $40 \pm 3 / 21 \pm 1{ }^{\circ} \mathrm{C}$ under weakly inductive). Although more dry matter assimilation can be expected under high light conditions, greater increase in respiration at high temperatures can lower dry matter accumulation.

It took longer for zinnia to flower under the strongly inductive photoperiods ( $\approx 36 \mathrm{~d}$ during strongly inductive and $\approx 23 \mathrm{~d}$ during weakly inductive photoperiod). However, flower initiation took place at the fifth node during strongly inductive photoperiods and at the sixth node during weakly inductive photoperiods (data not shown). Bract primordia initiation occurred uniformly under all treatments with a slight delay in floral primordia initiation under the $\mathrm{A}_{\mathrm{FR}}$ film chambers compared to the control plants during strongly inductive photoperiods (Table 3 ). There were no differences in the floral meristem initiation or development among treatments under weakly inductive photoperiods. This indicates that flower initiation was slightly delayed under weakly inductive photoperiods but warm conditions prevailing during the weakly inductive photoperiods probably accelerated flower development causing zinnia to flower earlier during weakly inductive photoperiods. Hourly day and night temperatures were not recorded in the experiments reported here due to technical difficulties. Although the maximum temperatures recorded may be higher than the optimum, temperature data from a separate experiment indicated that plants were only exposed to the extreme temperatures for a short period of time during the afternoons. Boyle et al. (1986) reported a linear correlation between temperature and the days to anthesis of zinnia.

Petunia 'Countdown Burgundy' is a quantitative LD plant in which flowering is hastened under photoperiods longer than 14 $\mathrm{h} \cdot \mathrm{d}^{-1}$ (Adams et al., 1998). During weakly inductive photoperiods, stems were slightly longer due to the delay in transition to the reproductive stage (Table 2). Plants grown under the $A_{F R}$ films during strongly inductive photoperiods had stems that were $10 \%$ shorter and total shoot dry weight that was reduced by $19 \%$ compared to the control plants. Shoot dry weight per unit length of stem was only slightly reduced. Days to anthesis was not affected by the $A_{F R}$ or $A_{R}$ films. Kubota et al. (2000) also reported that photoselective films with a high R:FR ratio reduced stem length but did not alter time to flower of petunia under strongly inductive photoperiods. Plants produced under the $A_{R}$ films showed a reduction in shoot dry weight compared to the control plants but stem elongation and days to anthesis were similar.

During weakly inductive photoperiods, $A_{\mathrm{FR}}$ films had a greater effect on shoot length and dry matter accumulation than during strongly inductive photoperiods. Stem length and shoot dry weight were reduced by $12 \%$ and $26 \%$, respectively, under the $\mathrm{A}_{\mathrm{FR}}$ film compared to the control plants. Anthesis was delayed by $5 \mathrm{~d}$ compared to control plants. Petunia grown under the $A_{R}$ film had longer stems, lower shoot dry weight, and flowered in the same time as the control plants. In petunia, initiation and development of floral structures was not affected by the photoselective films during strongly inductive photoperiods (Table 3 ). However, during weakly inductive photoperiods, initiation of the floral primordia was significantly delayed and overall development of the floral 
CONTROL
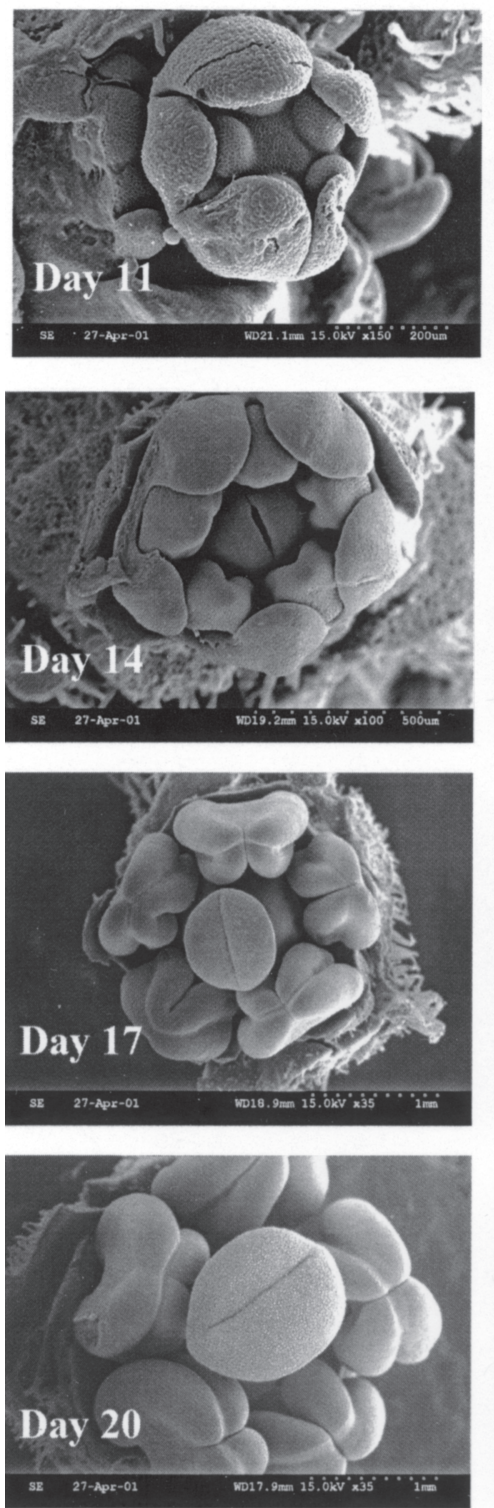

$\mathbf{A}_{\mathrm{R}}$
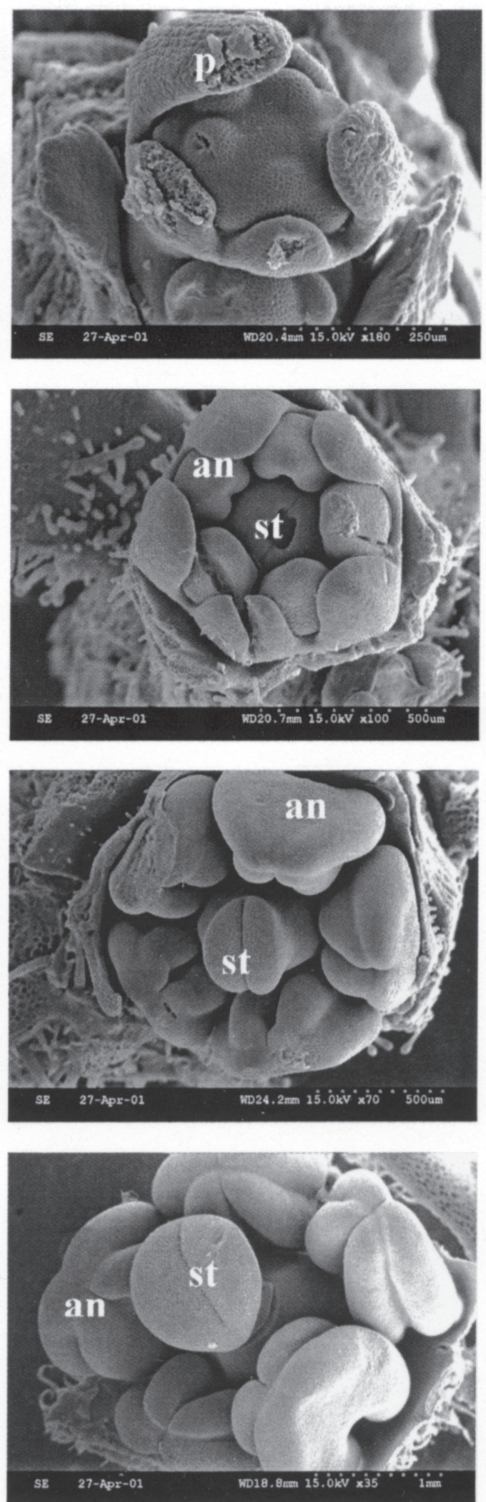

$\mathbf{A}_{\mathbf{F R}}$
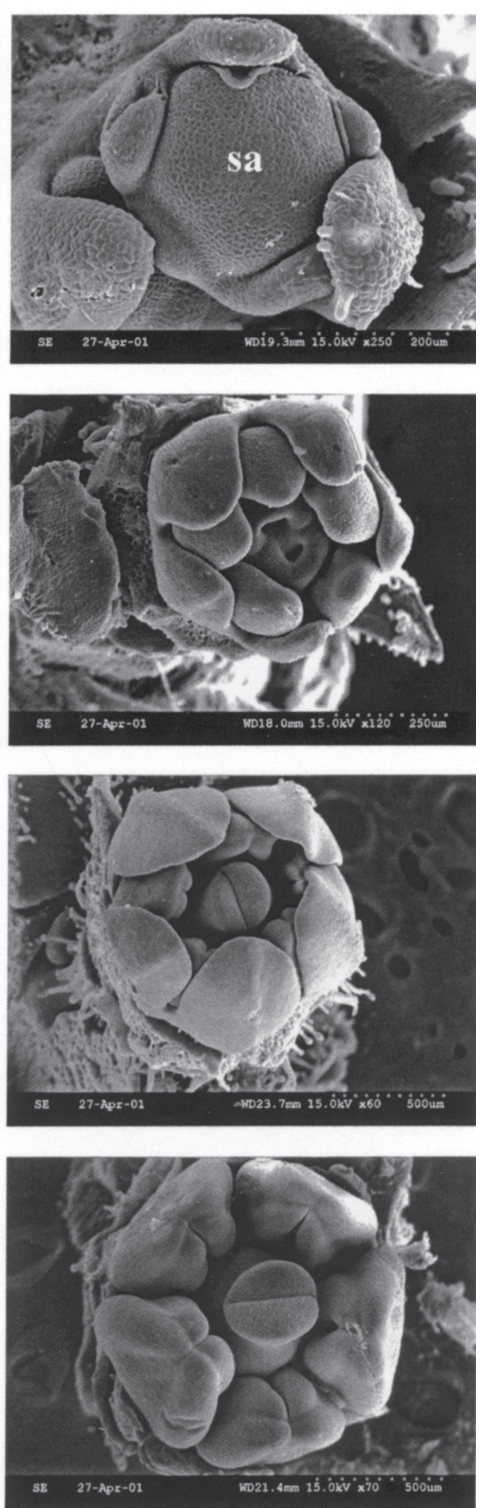

Fig. 2. Influence of control, red light absorbing $\left(\mathrm{A}_{\mathrm{R}}\right)$, and far red light absorbing $\left(\mathrm{A}_{\mathrm{FR}}\right)$ films on floral development of Petunia $\times$ hybrida during weakly inductive photoperiods; $\mathrm{an}=$ anther; $\mathrm{p}=$ petal; $\mathrm{sa}=$ shoot apex; $\mathrm{st}=$ stigma $)$.

meristem was slower than control plants (Table 3, Fig. 2).

Anthesis of petunia was delayed by 13 days in experiment 1 which was conducted during a weakly inductive photoperiod. The greater delay in flowering may be due to differences in the time of production of plants. Experiment 1 was conducted during November to January where plants received a 10.5 -h photoperiod with about $9.5 \mathrm{~mol} \cdot \mathrm{m}^{-2} \cdot \mathrm{d}^{-1} P P F$. Experiment 2 was conducted during February to April where the photoperiod was $12 \mathrm{~h}$ and plants received about $11.5 \mathrm{~mol} \cdot \mathrm{m}^{-2} \cdot \mathrm{d}^{-1} P P F$. Petunia anthesis has been reported to hasten as the day length increases (Adams et al., 1998). The differences in photoperiod therefore, may partly explain the differences noted in the delay in anthesis late in the weakly inductive cycle.

In summary, results show that $A_{\mathrm{FR}}$ films were effective in reducing stem elongation of most of the species tested but anthesis can be affected depending on the plant species and the production season. In general, anthesis of SD plants (cosmos, chrysanthemum, zinnia) or DN plant (miniature rose) was not significantly affected by the $A_{F R}$ films regardless of the production time. The $A_{F R}$ films have the most influence on anthesis of LD plants. During strongly inductive photoperiods (long days), $\mathrm{A}_{\mathrm{FR}}$ films did not affect anthesis but, under weakly inductive photoperiods, floral initiation and overall development of the floral meristem can be delayed by the $\mathrm{A}_{\mathrm{FR}}$ films leading to considerable increase in production time if LD plants were produced off season. However, daylength extension with electric light sources could overcome this delay in anthesis yet achieve the benefit of $\mathrm{A}_{\mathrm{FR}}$ films for height reduction without the use of chemical growth regulators.

\section{Literature Cited}

Adams, S.R.,P. Hadley, and S. Pearson. 1998. The effects of temperature, photoperiod, and photosynthetic photon flux on the time to flowering of petunia 'Express Blush Pink'. J. Amer. Soc. Hort. Sci. 123:577-580. 
Bagnall, D.J. 1993. Light quality and vernalization interact in controlling late flowering in Arabidopsis ecotypes and mutants. Ann. Bot. 71:75-83.

Boyle, T.H. and D.P. Stimart. 1983. Developmental responses of Zinnia to photoperiods. J. Amer. Soc. Hort. Sci. 108:1053-1059.

Boyle, T.H., D.P. Stimart, and M.S. McIntosh. 1986. Seasonal variation in vegetative and reproductive development in Zinnia elegans Jacq. J. Amer. Soc. Hort. Sci. 111:260-266.

Cerny, T.A., S. Li, and N.C. Rajapakse. 2000. Shedding new light on greenhouse production. Greenhouse Product News 10(4):16-19.

Cremer, F., A. Havelange, H. Saedler, and P. Huijser. 1998. Environmental control of flowering time in Antirrhinum majus. Physiol. Plant 104:345-350.

Kim, H.Y., T. Abe, H. Watanabe, and Y. Suzuki. 1989. Changes in flower bud development of Zinnia elegans Jacq. as influenced by the growth retardant S-07. J. Hort. Sci. 64:81-89.

Kubota, S., T. Yamato, T. Hisamatsu, S. Esaki, R. Oi, M.S. Roh, and M. Koshioka. 2000. Effects of red- and far-red rich spectral treatments and diurnal temperature alternation of the growth a development of Petunia. J. Japan Soc. Hort. Sci. 69:403-409.

McMahon, M.J., J.W. Kelly, D.R. Decoteau, R.E. Young, and R. Pollock. 1991. Growth of Dendranthema $\times$ grandiflorum (Ramat.) Kitamura under various spectral filters. J. Amer. Soc. Hort. Sci. 116:950-954. Mortensen, L.M. and E. Stromme. 1987. Effects of light quality on some greenhouse crops. Scientia Hort. 33:27-36.

Oyaert, E., E. Volckaert, and P.C. Debergh. 1999. Growth of chrysanthemum under coloured plastic films with different light qualities and quantities. Scientia Hort. 79:195-205.

Rajapakse, N.C. and J.W. Kelly. 1992. Regulation of chrysanthemum growth by light quality. J. Amer. Soc. Hort. Sci. 117:481-485.

Rajapakse, N.C. and J.W. Kelly. 1995. Spectral filters and growing season influence growth and carbohydrate status of chrysanthemum. J. Amer. Soc. Hort. Sci. 120:78-83.

Runkle, E.S. and R.D. Heins. 2001. Specific functions of red, far red, and blue light in flowering and stem elongation of long-day plants. J. Amer. Soc. Hort. Sci. 126:275-282.

Sager, J.C., W.O. Smith, J.C. Edwards, and K.L. Cyr. 1988. Photosynthetic efficiency and phytochrome photoequilibrium determination using spectral data. Trans. Amer. Soc. Agr. Eng. 31:1882-1887.

vanHaeringen, C.J., J.S.West, F.J. Davis, A. Gilbert, P. Hadley, S. Pearson, A.E. Wheldon, and R.G.C.Henbest. 1998. The development of solid spectral filters for the regulation of plant growth. Photochem. Photobiol. 67:407-413. 